\title{
IMPORTANT PERSONS IN THE TEXT
}

Prince Fushimi-An Imperial Prince, he was Navy Chief of Staff until April 9, 1941.

Hara Yoshimichi-President of the Privy Council, a group of distinguished leaders who collectively advised the Emperor. He often asked questions in the Imperial Conferences on behalf of the Emperor. He did not favor war with the United States.

Hiranuma Kiichiro-A former Prime Minister, he served as Minister for Home Affairs in the second and third Konoye Cabinets. Although a long-standing leader of the Right, he was shot by an ultranationalist in August 1941 because of his failure to resign after Matsuoka's ouster.

Emperor Hirohito-He was opposed to war with the United States because of the high risks involved. He tried to use his personal influence to avoid war, but in the end was unsuccessful.

Hoshino Naoki-He had worked with General Tojo in Manchuria, and Tojo appointed him Chief Secretary of the Cabinet in October 1941. He had previously served as President of the Planning Board.

Ikawa Tadao-Formerly an official in the Ministry of Finance, he served as an unofficial negotiator in the early stages of the negotiations between the United States and Japan.

Ito Seiichi-Appointed as Navy Vice Chief of Staff on September 1, 1941, he supported what the lower echelons of the Navy had been saying: that a decision for war or peace could not be delayed.

Iwakura Hideo-A colonel in the Japanese Army, he was sent to Washington to advise Ambassador Nomura Kichisaburo. He was one of the principal authors of the document known as the "Draft Understanding."

Prince Kan'in-An Imperial Prince, and Army Chief of Staff until October 3, 1940. 
Kawada Isao-Finance Minister during the second Konoye Cabinet, he had a long career in the government service and had previously been Chief Secretary of the Cabinet.

Kaya Okinori-He accepted the post of Finance Minister in Tojo's Cabinet only after being assured that efforts to achieve a settlement with the United States would be continued. He had been a civil servant in the Finance Ministry.

Kondo Nobutake-Navy Vice Chief of Staff from October 1939 to September 1941.

Konoye Fumimaro-Prince Konoye was a member of the Fujiwara Clan and distantly related to the Emperor. He served in the House of Peers and Privy Council, and was Prime Minister on three occasions in the late 1930's and 1940-41. He felt that war with the United States was inadvisable, but he was not forceful enough to stop the trend toward war.

Kurusu Saburo-A career diplomat, he was sent to Washington in November 1941 to assist Ambassador Nomura. Official Washington did not like him, perhaps because of his part in the signing of the Tripartite Pact.

Matsuoka Yosuke-Matsuoka was a fiery, sometimes imprudent, and often intransigent advocate of an aggressive, expansionist Japan. He had received his college education in the United States, and had served as president of the South Manchuria Railroad. He favored a close alliance with Germany.

Muto Akira-Lt. General Muto was Chief of the Military Affairs Bureau of the War Ministry, which was in charge of political affairs involving the army. As head of this important bureau, he exercised considerable influence behind the scenes.

Nagano Osami-Admiral Nagano was Navy Chief of Staff from early 1941 until February 1944. Although he opposed war with the United States at first, he later became a strong advocate of immediate action in order to prevent a further decline in Japanese strength.

Nomura Kichisaburo-Admiral Nomura was appointed Ambassador to the United States in December 1940, in part because he was personally acquainted with President Roosevelt. He was accepted by most of Washington as a diplomat genuinely striving for an agreement between the two nations. His difficulties with the English language, his unprofessional methods, and his attitude toward di- 
plomacy often tangled official communications between the two governments.

Ogura Masatsune-Finance Minister in the third Konoye Cabinet. Oikawa Koshiro-Admiral Oikawa was Navy Minister from September 1940 to October 1941. During the October debates he continued to hold reservations about war with the United States but would not take a strong stand against war.

Oka Takasumi-As Chief of the Naval Affairs Bureau of the Navy Ministry, he was Muto's naval counterpart.

Sawada Shigeru-Sawada was Army Vice Chief of Staff from October 1939 to November 5, 1940.

Shimada Shigetaro-Before becoming Navy Minister in Tojo's Cabinet, he had served as Navy Vice Chief of Staff and as Commanderin-Chief of the China Fleet.

Sugiyama Gen-General Sugiyama became Army Chief of Staff in 1940. After the United States froze Japanese funds in July 1941, he took the position that further negotiation was useless. His attitude may be inferred from his statement: "If you are strong, the other side will back down."

Suzuki Teiichi-A professional Army officer, he once headed the Asia Development Board. At Konoye's invitation, he became head of the Planning Board in April 1941. He later complained that his work was hampered by his inability to get vital information from the armed forces.

Tanabe Moritake-He succeeded Tsukada as Army Vice Chief of Staff on November 6, 1941.

Togo Shigenori-A career diplomat, Togo had been Ambassador to Berlin but was sent to Moscow because he opposed the Tripartite Pact. Dismissed while Matsuoka was in power, he remained inactive until he was made Foreign Minister by General Tojo. He took office believing that the major cause of the deadlock between the United States and Japan was the question of stationing troops in China, and that if Japan would make concessions, peace might be possible.

Tojo Hideki-General Tojo established a reputation in the Army as an able administrator, and became War Minister in 1940. As War Minister he often advocated strong policies; but as Prime Minister he was more cautious, partly because of an increased sense of re- 
sponsibility, and partly because of the personal influence of the Emperor.

Toyoda Teijiro-Admiral Toyoda held the post of Minister of Commerce, Industry, Overseas Affairs in the second Konoye Cabinet, and that of Foreign Minister in the third Konoye Cabinet. He believed that Japan should not become too closely tied to Germany and instead should seek to improve relations with the United States.

Tsukada Ko-He was appointed Army Vice Chief of Staff in November 1940, and reflected the views of a clique of younger officers who favored a war policy.

Yoshida Zengo--He was forced to resign his post as Navy Minister in September 1940 because of an illness presumably brought on by his opposition to the Tripartite Pact. 